\title{
Analysis Physical and Mechanical of Particle Board Raw Material Nipah Fruit Fiber
}

\author{
M. Saddikin, Hendri Nurdin, Hasanuddin and Primawati \\ Jurusan Teknik Mesin, Fakultas Teknik, Universitas Negeri Padang, Indonesia
}

\begin{tabular}{|c|c|}
\hline Article Info & ABSTRACT \\
\hline Article history: & The raw materials of the timber industry, especially furniture, are increasingly \\
\hline Received Jan $16^{\text {th }} 2018$ & difficult to obtain in the quantity and quality needed. The development efforts \\
\hline Revised March $21^{\text {th }}, 2018$ & carried out were utilizing Nipah coir waste as a raw material for making \\
\hline Accepted May $07^{\text {th }}, 2019$ & particle boards. Particle boards are panel boards made of wood particles or \\
\hline & $\begin{array}{l}\text { materials containing ingnocellulose. Nipah plants contain } 27.3 \% \text { lignin and } \\
36.5 \% \text { cellulose which has the potential to be used as raw material for }\end{array}$ \\
\hline Keywords: & $\begin{array}{l}\text { particleboard production. This study aims to reveal the physical and } \\
\text { mechanical properties of particleboards made from Nipah fruit fibre with }\end{array}$ \\
\hline Nipah Fiber & adhesive using tapioca flour. The making of particle board is done with a ratio \\
\hline Tapioca & of $90 \%: 10 \%, 80 \%: 20 \%, 70 \%: 30 \%, 60 \%: 40 \%$, by giving a pressure of 100 \\
\hline Particle Board & $\mathrm{kg} / \mathrm{cm}^{2}$. Particle testing is carried out according to the JIS A 5908 standard \\
\hline Physical properties & (2003). From this study, the optimum results were obtained in variations of \\
\hline Mechanical properties & $\begin{array}{l}\text { 60\%:40\%. The particle physical properties which have an average density } \\
\text { value of } 1.15 \mathrm{gr} / \mathrm{cm} 3 \text { and an average moisture content of } 5.8 \% \text {. While the } \\
\text { mechanical properties obtained by the value of Modulus of Elasticity an } \\
\text { average of } 21,188.93 \mathrm{~kg} / \mathrm{cm}^{2} \text {. This shows the particle board variations of } \\
60 \%: 40 \% \text { produced to meet the JIS A 5908 (2003) standard. Based on the } \\
\text { analysis of the quality variations } 60 \%: 40 \% \text { of particle boards can be } \\
\text { recommended as raw materials for interior furniture. }\end{array}$ \\
\hline
\end{tabular}

\section{Corresponding Author:}

M. Saddikin,

Jurusan Teknik Mesin, Fakultas Teknik, Universitas Negeri Padang

Jln. Prof. Dr. Hamka Air Tawar, Padang (25131), Sumatera Barat, Indonesia

Email: m_saddikin@yahoo.co.id

\section{INTRODUCTION}

Current technological developments and advancements are so rapid, one of them is technology in the field of materials. The main materials used in industrial products are metal and non-metallic materials. Particle board is a material that many people glance at and are referred to as non-metallic materials. Particle boards are widely used in a variety of products. Globally particle boards were developed as a substitute for metal materials that are widely used before particle board development.

Some research on particle boards in developing particle boards from waste. Research on particle board models where the yield of the particle board density was $0.6 \mathrm{gr} / \mathrm{cm} 2$ at a variation of 40:60 using resin adhesives. While the board using adhesive starch glue obtained a density value of $0.44 \mathrm{gr} / \mathrm{cm} 2$ at a variation of 50:50 [1]. This shows that the particle board using tapioca adhesive produces a low density compared to particle board using resin adhesives. Other research, namely in variation 1: 6 particleboard made from coconut fibre raw material using kopal glue adhesive got the best results [2]. The mixture composition, application of adhesive, and raw material of mesh particles affects the particle board [3]. The development of particle board behaviour studies has been done by conditioning compaction pressure in the manufacturing process which can affect the increased fracture constancy behaviour [4].

Particle board is one type of wood product or wood panel made of wood particles or other lignocellulosic material which is bonded with adhesive then pressed [5]. Based on this, one of the plants containing lignocellulose is the Nipah plant which has the potential to be used as raw material for making particle boards. Wood powder or wood particles have the same chemical properties as wood: the content of lignin, cellulose, silica and ash content [6]. Nipah plants grow naturally, utilization by the community is still limited which lives around the beach for daily needs. For example midribs for firewood, leaves for the roof of the house and Nipah leaf bones for broomsticks. The part of the Nipah plant which is used as particle board material in the form of Nipah fruit fibre where the contents of the Nipah fruit have been taken for food, namely ko lang- 
Kaling. So that the Nipah fibre is a waste that can be reused after processing. Based on this, one of the efforts that can be done to increase the economic value of Nipah fruit fibre waste is the technology of utilizing Nipah fruit fibre waste as the raw material for making particle board.

The process of utilizing the Nipah fruit fibre was carried out by developing a technological process so that there was a diversification of the use of agricultural waste into particle board engineering material. Particle engineering innovation due to its features, so it can reduce environmental disturbances. Before the particleboard made from Nipah fibre is produced further, it is necessary to evaluate the quality characteristics of the particle board according to the standard JIS A 5908-2003 [7]. As the development of raw materials for furniture or furniture with characteristics that are recommendations towards furniture manufacturers. The purpose of this study was to use Nipah fruit fibre waste into particle board and to know the characteristics of particleboards made from tapioca starch fibre.

\section{METHOD}

The research method used is a type of experimental research. The experimental research method is a research method that is used to find the effect of certain treatments on others in controlled conditions [8]. The object of the research studied was particleboard made from Nipah fruit fibre adhering to tapioca. The tools used are counter machines, jack presses, scales, ovens, moulds of $25 \mathrm{~cm} \times 25 \mathrm{~cm} \times 1.2 \mathrm{~cm}$, aluminium foil, machetes, basins, while the materials used are Nipah fruit fibres, tapioca adhesive.

Comparison of particle variations affects the strength of the particle board [9]. The steps for making particle board from (1) provide the main raw material for palm fruit fiber and tapioca adhesive, compare the variations of $90 \%: 10 \%, 80 \%: 20 \%, 70 \%: 30 \%$, and $60 \%: 40 \%$; (2) Insert the material into the aluminium foil coated printer measuring $25 \mathrm{~cm} \times 25 \mathrm{~cm} \times 1.2 \mathrm{~cm}$; (3) do cold pressing by pressing with a pressure of $100 \mathrm{~kg} /$ $\mathrm{cm}^{\wedge} 2$; (4) after that the heat is pressed at a temperature of $1000 \mathrm{C}-1200 \mathrm{C}$ for 60 minutes; (5) The particle board sheet which has been hot pressed, removed from the printer and left for about 3 hours for hardening to occur; (6) then conducts drying conditioning for one week to achieve uniform water content distribution and release residual stresses on the board due to compression; (7) Further cutting the test sample in accordance with JIS A 5908-2003.

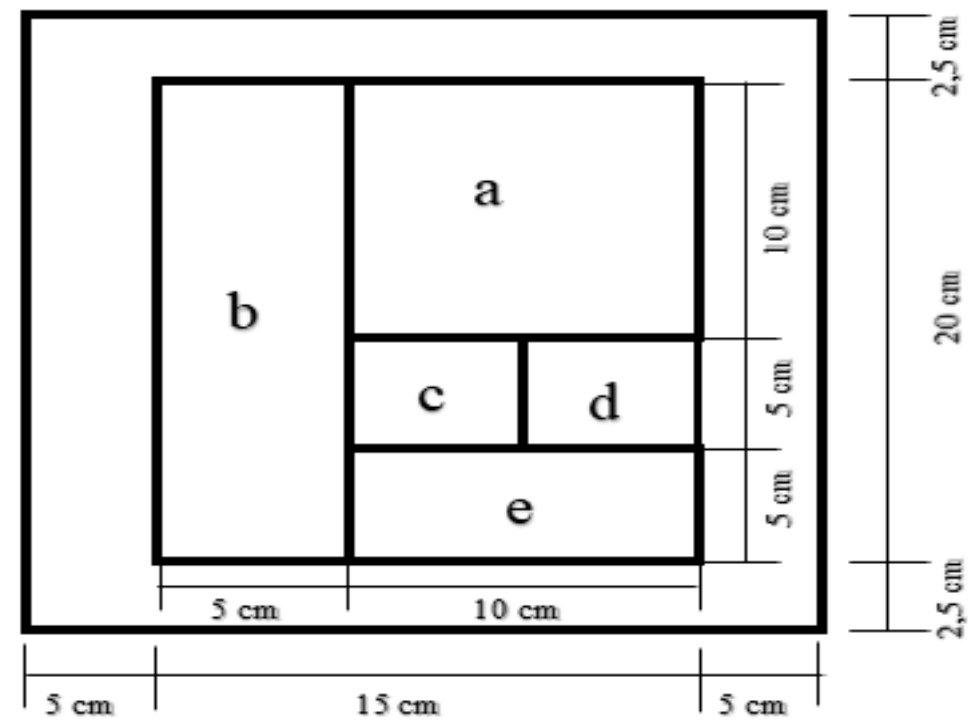

Information:

Fig.1. Cutting Pattern Test Example
a. Examples of density tests
b. Examples of flexural firmness (modulus of elasticity / MoE) and broken firmness (modulus of rupture / MOR).
c. Examples of water absorption and thick development tests.
d. Example of water content test.
e. e. Screw holding strength test example. 
Particle testing physical and mechanical properties based on JIS A 5908-2003.

Density

Water content

Modulus of Elastisitas (MoE)

$$
\begin{array}{ll}
: & \rho=\frac{m}{V} \\
: & \mathrm{KA}=\frac{B 2-B 1}{B 1} \times 100 \% \\
: & \mathrm{MoE}=\frac{\mathrm{P} \cdot \mathrm{L}^{3}}{4 \cdot \mathrm{y} \cdot \mathrm{b} \cdot \mathrm{h}^{3}}
\end{array}
$$

\section{RESULT}

The research that has been done is obtained by physical and mechanical properties of particle board, Particle Test results of particle board physical properties in the form of density values. Density is the number of masses per unit volume. The higher the overall density of the particle board, the higher the strength and stiffness of the particle board, the detrimental effect on the physical properties of the particle board is influenced by dimensional stability [10]. In Figure 2 a graph shows the average value of the test results for particle board density.

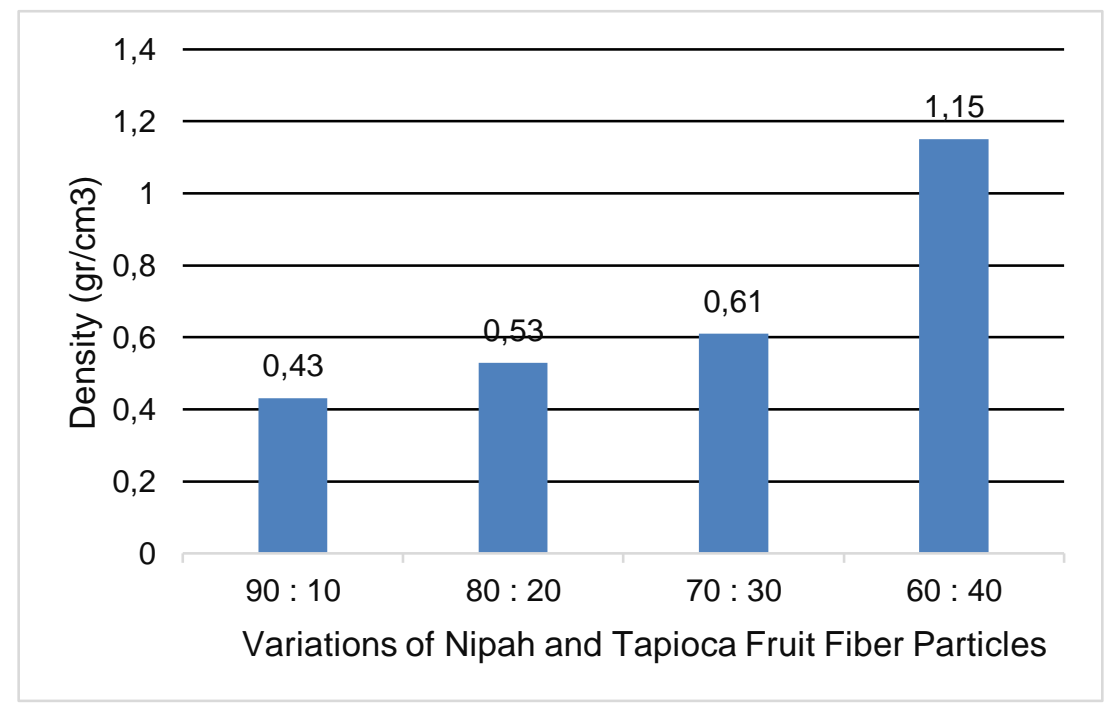

Fig. 2. Graph of Average Density Value

Figure 2 shows that the average value of particle board density produced ranges from $0.43-1.15 \mathrm{gr} / \mathrm{cm} 3$. JIS A 5908-2003 which requires $0.40-0.90 \mathrm{gr} / \mathrm{cm} 3$. The results of this study indicate that the particle board density values vary by 90:10, 80:20, 70:30 according to JIS A 5908-2003. The physical structure and shape of particles of raw materials affect density [11]. From figure 2, the average maximum density value is $1.15 \mathrm{gr} /$ $\mathrm{cm} 3$ at the variation of 60:40. The particle board density value tends to increase along with the increasing amount of adhesive used, this agrees with [12]. From the evaluation of the 60:40 particle board quality it is also appropriate to be used as raw material for interior furniture, because of the high density of the particle board, the high strength.

Physical properties of particle board in the form of water content. Water content is the amount of water content contained in the particle board in a state of equilibrium with the surrounding environment. The high water content is caused by hygroscopic particle properties because it contains lignin and cellulose. The ingredients of lignin and cellulose are very easy to absorb and release water [13]. In figure 3, a graph of the particle board moisture content is shown. 


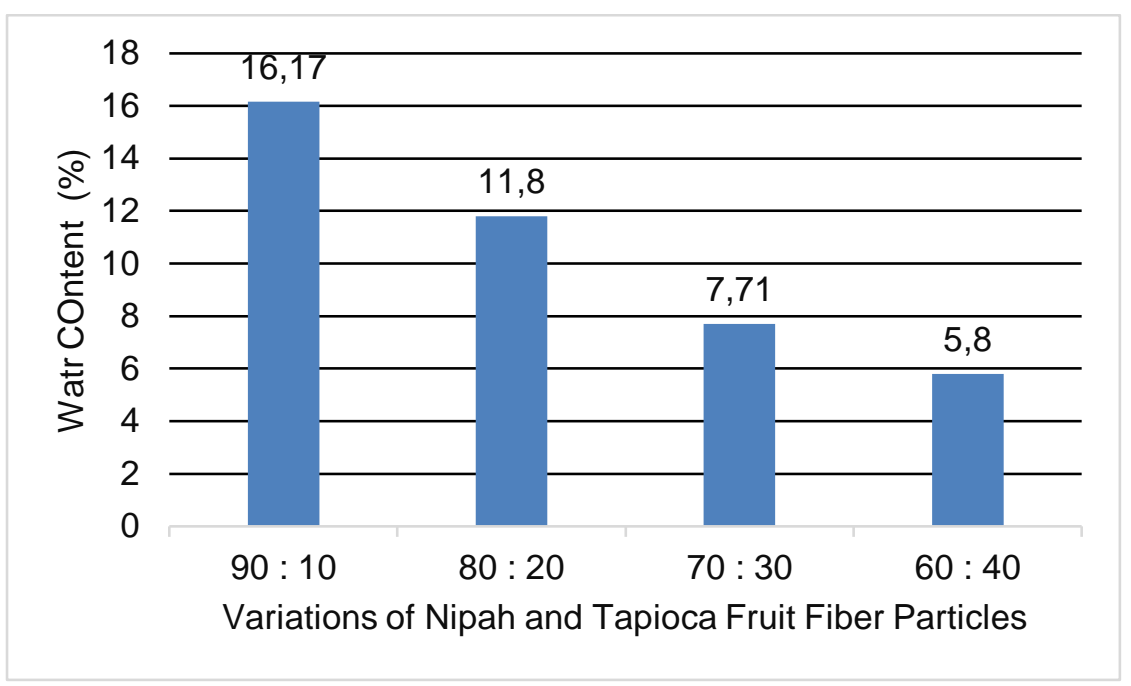

Fig. 3. Water Content Graph

Figure 3 shows that the average value of particle board water content ranges from 5.8-16.17\%. Under certain conditions, particle board particles that have hygroscopic properties can absorb and release water content when conditions of high air humidity [14]. JIS A 5908-2003 which requires 5-13\%. The results of this study indicate that the average value of particle board water content with variations of 60:40, 70:30, 80:20 produced meets JIS A 5908-2003. In figure 3 the minimum average value of water content is $5.8 \%$ at the variation of 60:40, that the higher the level of adhesive the lower the value of the water content produced, because many adhesives are able to produce bonds or adhesions between particles to close the cavity or pore on the particle board. This occurs because of the treatment of heat presses carried out during the compression process [15]. From the results of the evaluation of the 60:40 particle board quality it is also appropriate to be used as raw material for interior furniture.

While the Mechanical Properties of the Particle Board are in the form of Flexibility (Modulus of Elasticity / MoE). Flexural constancy (Modulus of Elasticity / MoE) is a measure of particle board resistance in maintaining shape changes due to the load and directly related to the particle board. The higher the MoE value, the more elastic. Data from the particle board Modulus of Elasticity $(\mathrm{MoE})$ test are presented in graphical form (Figure 4).

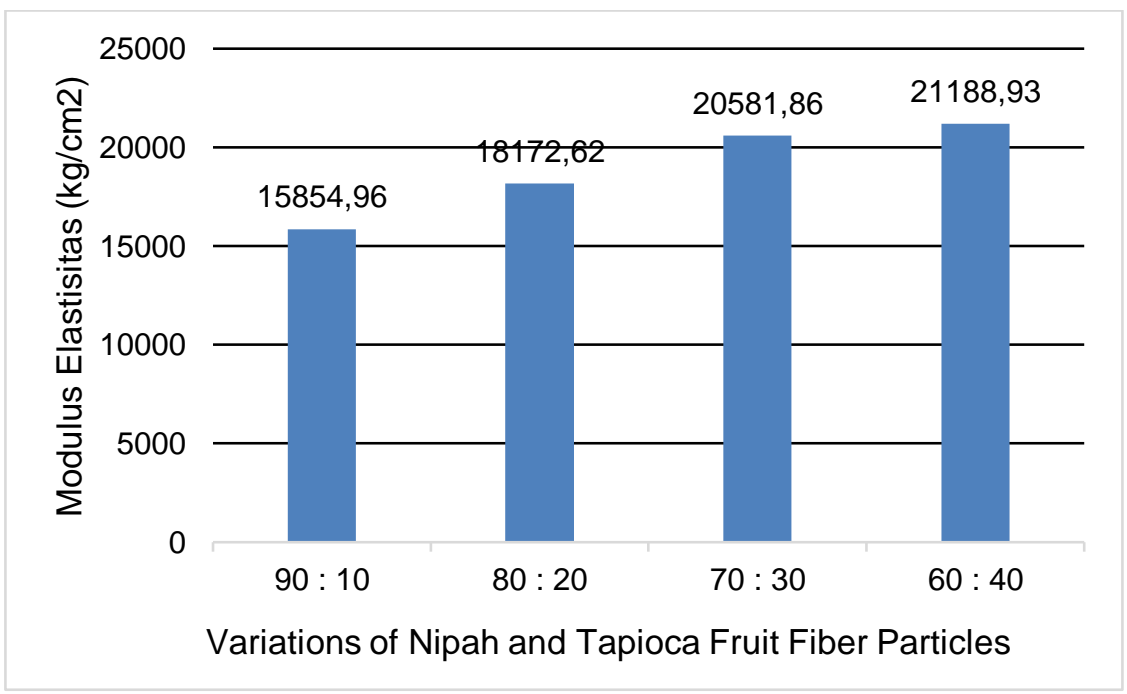

Fig. 4. Modulus of Elasticity (MoE) Graph

Figure 4 shows that the average value of Modulus of Elasticity (MoE) particle board ranges from 15854.96-21188.93 kg / cm2. JIS A 5908-2003 which requires a minimum MoE particle board MoE value of $20400 \mathrm{~kg} / \mathrm{cm}^{2}$. The results of this study indicate that the average value of particle board MoE variation is 70:30, 60:40 meets the JIS A 5908-2003 standard. In figure 4 the highest average value of MoE is obtained 
$21188.93 \mathrm{~kg} / \mathrm{cm} 2$ at variation 60:40, from figure 4 it can be stated that the more adhesive is used, the greater the particle board flexural (MoE) value. Particleboard with high density, the MoE or Flexural Resistance value tends to be high [16]. From the evaluation of the quality of particle board variation 60:40 it is very appropriate to be used as raw material for interior furniture. So that particleboards made from Nipah fruit fibre use tapioca adhesive can be recommended to be used as raw material for interior furniture fabrication.

\section{DISCUSSION}

Based on the results of particle board testing made from tapioca fibre, it was seen that the average value of the physical and mechanical properties of the particle board was density, moisture content and flexural constancy (modulus of elasticity). In figure 2 shows that the average value of the particle board density of various variations is produced. The average yield of density values obtained is a maximum value of $1.15 \mathrm{gr} /$ cm3 at variation 60:40, compared to other variations, from the results of this test it is stated that density characteristics are influenced by variations in the amount of adhesive used in making particle boards. Increased physical properties of density have a linear relationship with flexural constancy or modulus of elasticity [17]. Based on the particle board density value produced is called high-density particleboard, which is particle board with a density value above $0.8 \mathrm{gr} / \mathrm{cm} 2$ [18]. This shows that there is a fairly good bond between the main raw material of Nipah fruit fibre and tapioca adhesive and is also influenced by the pressing process given in the process of making the particle board. JIS A 5908-2003 requires a density value of $0.4-0.9 \mathrm{gr} / \mathrm{cm} 2$. Likewise with the characteristics of the modulus of elasticity (MoE) or flexural constancy in the variation of 60:40 tapioca adhesive obtained the maximum value of $21188.93 \mathrm{~kg} / \mathrm{cm} 2$. The strength of the particle board influences the ratio of the volume fraction contained in the particle board [19]. While the average value of water content obtained a minimum value of $5.8 \%$, at a variation of 60:40.

From Figure 3 it is shown that the more adhesive used the smaller the average value of the particle board water content. So that the ability of particleboards made using tapioca adhesives is influenced by variations in the adhesive used. When viewed from the results obtained in variation 60:40 it has fulfilled JIS A 5908-2003. From the evaluation of the quality of particle board variations of 60:40 can be used as furniture materials (furniture interior), namely, furniture that is not exposed to water or is in a humid place. So that particleboards made from Nipah fibre using tapioca adhesive can be recommended as furniture raw materials (interior furniture).

\section{CONCLUSION}

Based on the testing and research carried out on particleboards made from tapioca fibre with tapioca adhesive obtained optimum results, it can be concluded that they can utilize Nipah fruit fibres as raw material for making particle boards with tapioca adhesive. The making of particleboard made from Nipah fruit fibre is done by manual compression, then doing physical and mechanical testing and obtaining a density value of 1.15 $\mathrm{gr} / \mathrm{cm} 2$, moisture content of $5.8 \%$, and modulus of elasticity (MoE) $21188.93 \mathrm{~kg} / \mathrm{cm} 2$. From the manufacture and testing of particle boards, it can be stated that the factors that affect the strength of the particle board include variations in the mixture, raw material particles, adhesives, and forging processes. From the results of the data obtained by particle board of Nipah fibre with tapioca adhesive and compared with quality standards, the raw material for Nipah fruit fibre with tapioca adhesive can be recommended as a raw material for making particle board.

\section{REFERENCES}

[1] Nurdin, H, Purwantono, \& Nasrul Rivai. "Pengaruh Perekat Terhadap Kerapatan Papan Komposit Berbahan Baku Ampas Tebu”. Prosiding PB31 ISBN. 2014; 8-13.

[2] Sudarsono, Toto Rusianto, \& Yogi Suryadi. Pembuatan Papan Partikel Berbahan Baku Sabut Kelapa Dengan Bahan Pengikat Alami (Lem Kopal). Jurnal Teknologi, 2010; 3(1), 22-23.

[3] Nurdin, H., Fernanda, Y., \& Handayani, M. Analysis of Tensile Strength the Fiber Bagasse Particles Board with Resin Adhesives. Jurnal Teknomekanik, 2018; 1(1), 1-5. Journal homepage: http://teknomekanik.ppj.unp.ac.id/index.php/tekno/article/view/1

[4] Nurdin, H, Hasanuddin, \& Irzal. "Analysis Of Behavior Deflection Composite Particle Board Cane Baggase Using Adhesive Tapioca”. ICOMSET ISBN, 2015; 448-451.

[5] Maloney, T.M. Modern Particleboard dan Dry-Process Fiberboard Manufacturing. San Francisco: Miller Freeman, Inc. 1997.

Journal homepage: http://teknomekanik.ppj.unp.ac.id

DOI: https://doi.org/10.24036/tm.v2i2.2372 
[6] Departemen Kehutanan. Atlas Kayu Indonesia Jilid III. Pusat Penelitian dan Pengembangan Teknologi Hasil Hutan. Badan Penelitian dan Pengembangan Kehutanan. Bogor. 2004

[7] JIS. A 5908, Particles Boards, Japan: Japanese Standard Association, 2003.

[8] Sugiyono. Metode Penelitian Kuantitatif, Kualitatif, dan R\&D. Bandung: Alfabeta. 2017.

[9] Nurdin, H, Purwantono. Pengaruh Jenis Serat Pada Komposit Polimer Terhadap Kekuatan Tarik. Jurnal SAINTIKA ISSN. 2010; 10 (1).

[10] Bowyer J.L., Shmulsky, R., \& Haygreen, J.G. Forest Products and Wood Science An Introduction 4th Edition. IOWA State Press A Blackwell Publ, USA. 2003

[11] Abdurachman \& Nurwati, H. Sifat Papan Partikel Dari Kulit Kayu Manis. Jurnal Penelitian Hasil Hutan. 2011; 29(2): 128-141.

[12] Sirait, M. S., Setyawati, D., \& Rahmaniah, D. Sifat-Sifat Papan Komposit dari Sabut Kelapa, Limbah Plastik dan Perekat Urea Formaldehida. Pontianak: Universitas Tanjungpura. 2012

[13] Haygreen, J. G., Bowyer, J. L. Hasil Hutan dan Ilmu Kayu. Yogyakarta: Gajah Mada University Press. 1996.

[14] Nuryaman, A., Iwan, R., \& Pamona, S.N. Sifat Fisik Mekanik Papan Partikel dari Limbah Pemanenan Kayu. Jurnal Ilmu dan Teknologi Hasil Hutan. 2009; 2(2): 57 - 63.

[15] Massijaya, Y.M., Hadi, Y.S., Tambunan, B., \& I. Sunarni. Studi pembuatan papan patikel dari limbah kayu dan plastic polistirena. Jurnal Teknologi Hasil Hutan. 1999. 12 (2).

[16] Massijaya, Y. M. Industri Pengolahan Kayu Indonesia Ditinjau dari Sudut Ketersediaan Upaya Penyelamatan Bahan Baku. Bogor: Departemen Hasil Hutan Fakultas Kehutanan IPB Bogor. 2007.

[17] Rudi.S. \& Andriati A.H. Utilization of Eucalyptus Oil Refineries Waste for Cement Particle Board. International Journal of Sustainable Construction Engineering and Technology; 2012. 3(2) : 2 - 10.

[18] Maloney, T.M. Modern Particleboard dan Dry-Process Fiberboard Manufacturing. San Francisco: Miller Freeman, Inc. 1997.

[19] Nurdin, H., Pengaruh Penggunaan Jenis Serat Pada Komposit Polimer Terhadap Kekuatan Tarik. Zona Teknik. 2008; 3(2): 143-150.

\section{NOMENCLATURE}

$\begin{array}{llll}\rho & \text { Density }\left(\mathrm{gr} / \mathrm{cm}^{3}\right) & \mathrm{m} & =\text { heavy air dry test sample }(\mathrm{gr}) \\ \mathrm{V} & =\text { volume of air dry test sample }\left(\mathrm{cm}^{3}\right) & \mathrm{KA} & =\text { Water conten }(\%) \\ \mathrm{B} & =\text { Initial mass }(\mathrm{gr}) & \mathrm{B} 2 & =\text { Final Mass }(\mathrm{gr}) \\ \mathrm{MoE} & =\text { flexural constancy }\left(\mathrm{kg} / \mathrm{cm}^{2}\right) & \mathrm{L} & =\text { Disclaimer }(\mathrm{cm}) \\ \mathrm{P} & =\text { Maximum load }(\mathrm{kg}) & \mathrm{y} & =\text { Bending on Load }(\mathrm{cm}) \\ \mathrm{h} & =\text { Test sample thickness }(\mathrm{cm}) & \mathrm{b} & =\text { Test sample width }(\mathrm{cm})\end{array}$

